\title{
Effects of Vitex doniana leaf extract on aluminium-induced toxicity in male albino Wistar rats
}

\author{
O. E. Yakubu ${ }^{1,2^{*}}$, O. F. C. Nwodo ${ }^{2}$, C. $\mathrm{Imo}^{1}$, M. Abdulrahaman ${ }^{3}$, L. B. $\mathrm{Uyeh}^{4}$ \\ ${ }^{1}$ Department of Biochemistry, Federal University Wukari, Nigeria. \\ ${ }^{2}$ Department of Biochemistry, University of Nigeria, Nsukska, Nigeria. \\ ${ }^{3}$ Department of Microbiology, Kogi State University, Anyigba Nigeria. \\ ${ }^{4}$ Department of Medical Biochemistry, Cross River University of Technology, Calabar, Nigeria.
}

\section{ARTICLE INFO}

\section{Article history:}

Received on: $23 / 11 / 2015$

Revised on: 29/12/2015

Accepted on: 29/07/2016

Available online: 19/09/2016

\section{Key words}

Vitex doniana, Aluminum

Chloride toxicity, Albino

rats, ethanolic extract.

\begin{abstract}
This study was conducted to determine the effect of ethanolic leaf extract of Vitex doniana on the toxicity induced by aluminium chloride in male Wistar albino rats. A total of 15 male albino rats were used for the study and toxicity was induced using $100 \mathrm{mg} / \mathrm{kg}$ body weight (bw) $\mathrm{AlCl}_{3}$. They were grouped into three (five rats in each group): normal control, $\mathrm{AlCl}_{3}$ control and $\mathrm{AlCl}_{3}+100 \mathrm{mg}$ Vitex doniana respectively. The normal control group was fed with standard rat chow only, while the $\mathrm{AlCl}_{3}$ control group was orally administered $100 \mathrm{mg} / \mathrm{kgbw}$ $\mathrm{AlCl}_{3}$, and the $\mathrm{AlCl}_{3}+\mathrm{V}$.D group was orally administered $100 \mathrm{mg} / \mathrm{kgbw}$ extract following administration of $\mathrm{AlCl}_{3}$. The study was conducted for 7 days after which the effect of the extract was assessed following the animal sacrifice. Oral dose of $100 \mathrm{mg} / \mathrm{kg}$ bw extract of Vitex doniana did not show any significant change in TBARS level of liver and testes in the experimental groups, while the AST, ALT and ALP levels in $\mathrm{AlCl}_{3}$ control and $\mathrm{AlCl}_{3}+100 \mathrm{mg}$ Vitex doniana showed significant increase $(\mathrm{p}<0.05)$ and non-significant increase (except ALT which increased significantly) with control group respectively. The PCV and Hb levels did not show any significant $(\mathrm{p}>0.05)$ change from the control group, while there was no significant difference in bilirubin level among the different experimental groups. More research should therefore be done on this study to further understand the usefulness of ethanolic leaf extract of Vitex doniana, and encourage its application in herbal medicine.
\end{abstract}

\section{INTRODUCTION}

The attempt by mankind to use plants and plant products to cure diseases and relieve physical suffering is as old as creation [1,2]. Indigenous people in all ages had some knowledge of plants and through systematic trial and error approach, applied them to various uses. Thus the earliest attempts at the use of plants for medicines were based on speculation [3].

Traditional medicine has given us very useful synthetic clues of modern drugs in the past [4]. Most of these plant-derived drugs were originally discovered through the study of herbal cures and folk knowledge of traditional people and some of these could not be substituted despite the enormous advancement in synthetic chemistry [5].

* Corresponding Author

Ojochenemi Ejeh Yakubu, Department of Biochemistry, Federal

University Wukari,Nigeria.Email:oj4real_2007@yahoo.co.uk
The use of plants in the management and treatment of diseases started with life. In more recent years, with more recent research, it has been found out that many plants do indeed have medicinal values. Some medicinal plants used in Nigeria include Garcina kola, used in the treatment of asthma, Carica papaya, used as a remedy for hypertension, Ocimum basilicum, a cure for typhoid fever and Cola nitida, for treatment of bile [6]. Vitex doniana (verbenaceae), commonly called black plum, is widely distributed in the eastern and western parts of Nigeria. Various parts of the plant are used by traditional medicine practitioners in Nigeria in the management and treatment of several disorders which include rheumatism, hypertension, cancer and inflammatory diseases [7]. Earlier workers have reported the use of the fruits and leaves for medicinal purposes. The ability of an aqueous extract of Vitex doniana bark to protect the liver of albino rats from carbon tetrachloride-induced liver damage evaluated by measuring serum levels of Alanine aminotransferase (ALT), Aspartate aminotransferase (AST), Alkaline Phosphatase (ALP), bilirubin and total protein has been reported [8,9]. 


\section{MATERIALS AND METHODS}

\subsection{Animals}

15 male albino Wistar rats weighing between $130 \mathrm{~g}-210 \mathrm{~g}$ were procured from the animal house of the Department of Medical Biochemistry, Cross River University of Technology, Okuku Campus, Cross River State, Nigeria and kept in a clean cage to acclimatize for two weeks. They were monitored under standard laboratory conditions with $12: 12 \mathrm{hr}$ light/dark cycle at room temperature $\left(25^{\circ} \mathrm{C} \pm 2\right)$ and fed with standard rat chow and normal water.

\subsection{Plant Specimen}

Fresh leaves of Vitex doniana were obtained from Okuku village in Yala Local Government Area of Cross River State. They were sent to the Department of Biological Sciences, Cross River University of Technology, Calabar for identification and authentication. The leaves were air-dried under room temperature for three (3) weeks after which they were ground into powder using an electric blender. Three hundred gram (300g) of the sample was weighed and soaked in $1200 \mathrm{ml}$ of ethanol for $24 \mathrm{hrs}$ after which it was filtered using wattman no.1 filter paper. The filtrate was concentrated using a water bath at $40^{\circ} \mathrm{C}$. The filtrate was concentrated using a water bath at $40^{\circ} \mathrm{C}$, thereafter dissolved in water for the experiment.

\subsection{Preparation of Aluminum Chloride}

Two gram (2g) of Aluminium chloride salt was weighed and dissolved in $5 \mathrm{ml}$ of distilled water. The solution was prepared daily. The aluminium chloride solution was administered $100 \mathrm{mg} / \mathrm{kg}$ bw of rat.

\subsection{Experimental Design}

The rats were divided into three groups of five (5) rats each:

Group 1 was normal control which was fed with only standard rat chow and distilled water.

Group 2 was Aluminum Chloride control which was administered $100 \mathrm{mg} / \mathrm{kg}$ bw $\mathrm{AlCl}_{3}$ daily.

Group 3 was Aluminum Chloride + Vitex doniana:

The rats were administered with $100 \mathrm{mg} / \mathrm{kgbw}$ of Vitex doniana ethanolic extracts, one hour after administration of $100 \mathrm{mg} / \mathrm{kgbw}$ of $\mathrm{AlCl}_{3}$. The Aluminum and extract were administered for seven consecutive days.

\subsection{Animal sacrifice and sample collection}

The final weight of the animals was measured and the animals were sacrificed under chloroform anaesthesia. Blood samples were collected by cardiac puncture and their Kidneys, Liver and Testes were removed, weighed and rinsed in ice cold normal saline. The blood samples were collected into EDTA collection tubes and plain tubes for serum. The tissues were weighed and homogenized using a standard laboratory mortar and pestle. The homogenates were centrifuged and the supernatant was extracted for Thiobarbituric acid reactive substances (TBARS) analysis.

\subsection{Determination of Thiobarbituric Acid Reactive Substances (TBARS)}

The thiobarbituric acid reactive substance formation was measured as described by using $10 \%$ trichloroacetic acid (TCA) solution and $0.67 \%$ thiobarbituric acid (TBA) solution. $100 \mu \mathrm{l}$ of tissue homogenate was added to a test tube containing $2 \mathrm{ml}$ of TCA. $2 \mathrm{ml}$ of TBA was added and was incubated at $80^{\circ} \mathrm{c}$ for $30 \mathrm{~min}$ in a water bath. It was cooled immediately under ice and centrifuged at $3,500 \mathrm{rpm}$ for $10 \mathrm{mins}$. The absorbance of the solution was measured at $535 \mathrm{~nm}$ against a blank solution containing all but the sample. The TBARS was calculated using a molar extinction coefficient of $1.56 \times 105 \mathrm{M}^{-1} \mathrm{~cm}^{-1}$.

\subsection{Assay of Liver Enzymes}

Determination of liver enzymes namely: Alanine aminotransferase, Aspartate aminotransferase and alkaline phosphatase were carried out using the method described by Reitman and Frankel [10].

\subsection{Assay of Bilirubin}

The total and direct bilirubin assay were carried out based on the method of Jendrassik and Grof [11].

\subsection{Determination of haematological parameters}

The packed cell volume (PCV) and haemoglobin $(\mathrm{Hb})$ concentrations were determined using Abacus 280 auto haematology analyzer in General hospital Gboko, Benue State, Nigeria.

\section{RESULTS AND DISCUSSION}

\subsection{Thiobarbituric Acid Reactive Substances (TBARS) Level}

Results in table 1 show the level of Thiobarbituric acid reactive substances (TBARS) in liver and testes of $\mathrm{AlCl}_{3}$ intoxicated rats. The results show that there was no significant change ( $p>0.05)$ in TBARS level in Liver and Testes of $\mathrm{AlCl}_{3}$ intoxicated rats compared with the normal control. Administration of V.D extract did not cause any significant $(\mathrm{p}>0.05)$ increase or decrease in Liver and Testes TBARS level compared to the normal control.

Table 1: Effect of Vitexdoniana ethanolic extract on TBARS level in Liver and Testes of $\mathrm{AlCl}_{3}$ treated male Rats.

\begin{tabular}{ccc}
\hline \multirow{2}{*}{ GROUPS } & TBARS & TBARS \\
& LIVER(nmol/ml) & TESTES $(\mathbf{n m o l} / \mathbf{m l})$ \\
\hline CONTROL & $0.29 \pm 0.07^{\mathrm{a}}$ & $0.28 \pm 0.00^{\mathrm{a}}$ \\
$\mathrm{ALCL}_{3}$ & $0.33 \pm 0.05^{\mathrm{a}}$ & $0.39 \pm 0.04^{\mathrm{a}}$ \\
$\mathrm{ALCL}_{3}+$ V.D & $0.30 \pm 0.06^{\mathrm{a}}$ & $0.33 \pm 0.09^{\mathrm{a}}$ \\
\hline
\end{tabular}

- Each value represents the mean of 5 Rats \pm SD.

a- no significant change from control group at $\mathrm{p}<0.05$. 


\subsection{Liver Enzymes Activity}

Table 2 shows the result of liver enzymes activity in male rats induced with $\mathrm{AlCl}_{3}$. The present result shows that Alkaline Phosphatase (ALP), Aspartate aminotransferase (AST) and Alanine aminotransferase levels (ALT) activities in $\mathrm{AlCl}_{3}$ control and $\mathrm{AlCl}_{3}+100 \mathrm{mg}$ Vitex doniana showed significant increase $(\mathrm{p}<0.05)$ and non-significant increase (except ALT which increased significantly) respectively, compared with normal control group.

Table 2: Effect of Vitexdoniana ethanolic extract on some Liver enzymes of $\mathrm{AlCl}_{3}$ treated male Rats.

\begin{tabular}{cccc}
\hline GROUPS & ALP $($ U/l) & ALT (U/I) & AST (U/I) \\
\hline CONTROL $^{\text {a }}$ & $50.69 \pm 3.88^{\mathrm{a}}$ & $16.50 \pm 0.61^{\mathrm{a}}$ & $16.96 \pm 1.36^{\mathrm{a}}$ \\
$\mathrm{ALCL}_{3}$ & $56.52 \pm 4.67^{\mathrm{b}}$ & $19.34 \pm 0.61^{\mathrm{b}}$ & $19.88 \pm 1.90^{\mathrm{b}}$ \\
$\mathrm{ALCL}_{3}+$ V.D & $51.34 \pm 3.88^{\mathrm{a}}$ & $18.77 \pm .25^{\mathrm{b}}$ & $17.16 \pm 0.41^{\mathrm{a}}$ \\
\hline - Each value represents the mean of 5 Rats \pm SD. & \\
a- No significant change from control group at p<0.05. & \\
b- Significant change from control group at $\mathrm{p}<0.05$ &
\end{tabular}

\subsection{Serum Bilirubin Levels}

Table 3 shows the levels of serum bilirubin in $\mathrm{AlCl}_{3}$ treated rats. The levels of serum total and direct bilirubin was not significantly different in all the experimental groups when compared with the normal control.

Table 3: Effect of Vitexdoniana ethanolic extract on Bilirubin levels of $\mathrm{AlCl}_{3}$ treated male Rats.

\begin{tabular}{ccc}
\hline GROUPS & $\begin{array}{c}\text { TOTAL BILIRUBIN } \\
(\mathbf{m m o l} / \mathbf{l})\end{array}$ & $\begin{array}{c}\text { DIRECTBILIRUBIN } \\
(\mathbf{m m o l} / \mathbf{l})\end{array}$ \\
\hline CONTROL $^{\mathrm{a}}$ & $4.26 \pm 0.16^{\mathrm{a}}$ & $6.30 \pm 0.09^{\mathrm{a}}$ \\
$\mathrm{ALCL}_{3}$ & $6.40 \pm 0.60^{\mathrm{a}}$ & $8.92 \pm 0.22^{\mathrm{a}}$ \\
$\mathrm{ALCL}_{3}+$ V.D & $5.50 \pm 0.05^{\mathrm{a}}$ & $7.16 \pm 0.51^{\mathrm{a}}$ \\
\hline
\end{tabular}

- Each value represents the mean of 5 Rats \pm SD

a- No significant change from control group at $\mathrm{p}<0.05$.

\subsection{Hematological Parameters}

Table 4 shows the result of some hematological parameters in $\mathrm{AlCl}_{3}$ intoxicated rats. The table shows that there was no significant change in Packed Cell Volume and Hemoglobin levels of rats treated with $\mathrm{AlCl}_{3}$ as well as those treated with $\mathrm{AlCl}_{3}$ + V.D as compared with the normal control.

Table 4: Effect of Vitexdoniana ethanolic extract on some hematological parameters of $\mathrm{AlCl}_{3}$ treated male Rats.

\begin{tabular}{ccc}
\hline GROUPS & PCV $(\%)$ & HB(g/dl) \\
\hline CONTROL & $14.12 \pm 2.01^{\mathrm{a}}$ & $47.53 \pm 10.65^{\mathrm{a}}$ \\
$\mathrm{ALCL}_{3}$ & $12.17 \pm 2.72^{\mathrm{a}}$ & $39.21 \pm 8.97^{\mathrm{a}}$ \\
$\mathrm{ALCL}_{3}+$ V.D & $13.22 \pm 1.34^{\mathrm{a}}$ & $43.56 \pm 5.23^{\mathrm{a}}$ \\
\hline
\end{tabular}

- Each value represents the mean of 5 Rats \pm SD

a- No significant change from control group at $\mathrm{p}<0.05$.

\section{DISCUSSION}

Aluminum Chloride has been reported to have prooxidant activity, it is considered to be a non-redox active metal that promotes biological oxidation [12]. Vitex Doniana extracts on the other hand has anti-oxidant and free radical scavenging activity which is of very significant health effect to humans [13].

The results of the present study show that Aluminum Chloride did not cause significant change in the TBARS levels in Liver and testes of rats. The Aluminum control group as well as the group treated with Aluminum Chloride + ethanolic leaves extract of $V$. doniana did not show any significant change when compared with the normal group. This result however is inconsistent with previous studies [14] that reported significant increase in TBARS level of $\mathrm{AlCl}_{3}$ treated rats and may be due to the duration of the experiment.

In the present study, there was significant change in Liver enzyme activity, Aspartate aminotransferase, Alkaline phosphatase and Alanine aminotransferase showed a significant $(\mathrm{p}<0.05)$ increase in the group treated with Aluminum Chloride when compared with the normal group. However, treatment with the V.D extract showed significant $(\mathrm{p}<0.05)$ decrease in enzyme activities. This result is in consonance with the previous report of increased enzyme activity in serum of $\mathrm{AlCl}_{3}$ treated rats [14]. The result shows that $\mathrm{AlCl}_{3}$ causes oxidative damage which led to the leakage of Liver enzymes into the circulation [15]. On the other hand, $\mathrm{AlCl}_{3}$ did not cause a significant change in serum bilirubin levels (total and direct bilirubin). Neither the group treated with $\mathrm{AlCl}_{3}$ alone nor those treated with $\mathrm{AlCl}_{3}+V$. doniana showed any significant changes. Change in bilirubin level is used as a marker for erythrocyte damage which may lead to jaundice [16]. Also, there was no significant change in the haematological parameters measured in rats induced with aluminum chloride as well as those treated with $\mathrm{AlCl}_{3}+V$. doniana as compared with the normal group. The result is not consistent with previous reports of high cellular damage and decrease in haemoglobin levels of $\mathrm{AlCl}_{3}$ treated rats [17]. This study however concludes that the duration of extract administration as well as $\mathrm{AlCl}_{3}$ administration is a major factor in determining the level of oxidative damage caused by Aluminum as well as the ameliorative effect of ethanolic extracts of $V$. doniana on the damage caused by Aluminum.

\section{CONCLUSION}

The results of the present study provide supporting evidence for the oxidative effect of aluminium chloride on several parameters in serum and tissues, and the ameliorating effect of Vitex doniana on aluminium chloride intoxication. This may be attributed to the time frame or duration of $\mathrm{AlCl}_{3}$ and extract administration. It is therefore concluded on the basis of previous and present study that aluminium chloride induces membrane damage and oxidative stress in tissues. Also, Vitex doniana possess ameliorating effect. Further work is however required in this study to understand the curative and preventive effect of ethanolic extracts of Vitex doniana on $\mathrm{AlCl}_{3}$ toxicity.

\section{Financial support and sponsorship: Nil.}

Conflict of Interests: There are no conflicts of interest. 


\section{REFERENCES}

1. Lira R, Casas A, Rosas-López R, Paredes-Flores M, Pérez-Negrón E, RangelL- Landa S, Solís L, Torres I, Dávila P. Traditional knowledge and useful plant richness in the Tehuacán-Cuicatlán Valley, Mexico, Econ. Bot. 2009; 63:271-287.

2. Mirutse G, Zemeda A, Thomas E, Zerihum W. An ethnobotanical study of medicinal plants used by the Zay people in Ethiopia, $J$ Ethnopharmacol.2003; 85:43-52.

3. Sofowora AE. The state of medicinal plant research in Nigeria, Ibadan University Press, Nigeria, 1993; pp.283.

4. Gilani AH, Rahman AU. Trends in ethnopharmacology. $J$ ofEthopharmacol; 2005;100:43-49.

5. Babalola EO. The persistence of African Traditional medicine in contemporary Nigeria Society. AfricanMarburgensia.1993;26:4.

6. Ladeji O, Okoye ZSC. Anti-hepatotoxic properties of Vitex doniana bark extract. Pharm. Biol.1996;34(5):355-358.

7. Shahraki MR, Zahedi AS, Sarkaki AR. The Effect of Aluminum Injection in Lateral Ventricle on Sex Hormones in Male Rat, Shiraz EMedical Journal . 2004; 5:1-10.

8. Yousef MI, and Salama AF. Propolis protection from reproductive toxicity caused by aluminium chloride in male rats. Food and Chemical Toxicology.2009; 47:1168-1175.

9. Guo CH, Lin CY, Yeh MS, Hsu GW. Aluminum-induced suppression of testosterone through nitric oxide production in male mice, Environment Toxicology Pharmacology. 2005; 19:33-40.

10. Reitman S, Frankel S.Amer. J. Clin. Path.1957. 28:56.

11. Jendrassik L, Gróf P. Vereinfachte photometrische Methoden zur Bestimmung des Blutbilirubins. Biochem Zeitschrift;1938; 297:82-9.

12. Turner T, Lysiak JJ. Oxidative Stress: A Common Factor in Testicular Dysfunction. Journal of Andrology. 2008; 29: 488-498.
13. Hoffman D. MedicalHerbalism: The Science and Practice of Herbal Medicine. Rochester, VT: Healing Arts Press.2003;13:62-120.

14. Hala AH, Inas ZA,Gehan MK. Grape seed extract alleviate reproductive toxicity caused by aluminium chloride in male rats. Journal of American Science.2010; 6(12):1201-1204.

15. Türkez H, Geyikoğlu F, Çolak S. The protective effect of boric acid on aluminum-inducedhepatotoxicity and genotoxicity in rats.Turk $J$ Biol.2011;35:293-301.

16. Christie S, Walker A. Vitex agnus-castus L. (1) A review of its traditional and modern therapeutic use; (2) current use from a survey of practitioners. Eur J Herbal Med.1999;3:29-45.

17. Aitken RJ, Roman SD. Antioxidant systems and oxidative stress in the testes, Oxidative Medicine and Cellular Longevity. 2008;1:15-24.

\section{How to cite this article:}

Yakubu, O. E., Nwodo, O. F. C., Abdulrahaman, M. and Uyeh, L. B. Effects of Vitex doniana leaf extract on aluminium-induced toxicity in male albino Wistar rats. J App Biol Biotech. 2016; 4 (05): 037-040. DOI: 10.7324/JABB.2016.40506 